\title{
PENENTUAN KANDUNGAN LOGAM ESENSIAL (Fe, Zn DAN Cu) DALAM DAUN SIRIH MERAH (Piper crocatum) SEGAR, AIR REBUSAN DAN AIR SEDUHANNYA DENGAN METODE SPEKTROSKOPI SERAPAN ATOM (SSA)
}

\author{
Indrawati $^{a}$, Willsant Saputra ${ }^{\mathrm{a}}$, Refilda $^{\mathrm{a}}$ \\ ${ }^{a}$ Laboratorium Kimia Lingkungan Jurusan Kimia FMIPA, Universitas Andalas \\ e-mail: loan_indrawati@yahoo.com
}

\begin{abstract}
Determination of essential metals $(\mathrm{Fe}, \mathrm{Zn}$ and $\mathrm{Cu}$ ) in red betel leaf has been carried out by using Atomic Absorption Spectrophotometer (AAS). Fresh and dry red betel leaf extracted in $75 \mathrm{~mL}$ by boiled and brewed distilled water for 5, 10, 15 and 20 minutes. In the fresh red betel leaf metal content $(\mathrm{Fe}, \mathrm{Zn}$ and $\mathrm{Cu})$ were $0,3257 \%, 0,173 \%$ and $0,0278 \%$ and the highest metal content $(\mathrm{Fe}, \mathrm{Zn}$ and $\mathrm{Cu})$ found in dry red betel leaf which were boiled for 20 minutes with the concentration $0,0539 \%, 0,0305 \%$ and $0,0128 \%$. Red betel leaf is a source of essential metals needed by the body.
\end{abstract}

Keywords: Atomic Absorption Spectrophotometry (AAS), Red betel leaf (Piper crocatum), decoction water, steeping water, $\mathrm{Fe}, \mathrm{Zn}$ and $\mathrm{Cu}$ 